\title{
The Role Of English For Banking Subject In Language And English Literature Study Program Faculty Of Language And Arts
}

\author{
A C Mamentu ${ }^{1}$ \\ ${ }^{1}$ Universitas Negeri Manado, Indonesia \\ corresponding author: 1 claramamentu@unima.ac.id
}

\begin{abstract}
English for Banking subject is offered to the students as an optional subject. This subject is offered to the students in order to anticipate the alumni that will be accepted in the banking related jobs. The aim of this research was to identify the role of English for Banking subject toward students' readiness in work fields. This research used qulitative method and linear regression analysis with sixteen students as total respondents who are the student of the fourth semester of Language and English Literature Study Program Faculty of Language and Arts UNIMA. The result of this research was the English for Banking has positive influential toward students' readiness to enter the banking realted job. The subject is suggested to be given in the Language and English Literature Study Program. This shows that the role of English for Banking subject is recommeded as an obligatory subject and not only as an optional subject.
\end{abstract}

Keywords: English for Banking, Role of English

\section{Introduction}

Language and English Literature Study Program is the one of study programs which is in English Education Department, Faculty of Language and Art Universitas Negeri Manado (UNIMA). One of the missions of Language and English Literature Study Program is to produce alumnus of bachelor degree that has Language and Literature background which is able to fulfill the demand of field work. The alumnus of this Study Program is expected able to master language study in English.

In fact, they were accepted in various of field work and many alumnus of this study program is able to work in the banking of field work. Whereas they learn about language and literature study program especially English which is not related to banking field. It can be predicted that when they are accepted, they will get confuse with the things that they do not understand about the work they faced. They need time to be adapted with their work which is not related to the subject that they learned.

English for Banking subject is the subject offered to the student as optional subject and begun in this semester. This subject is offered to the student in order to anticipate the alumnus that will be accepted in the banking of field work. Given 
material in this subject related to the terms of banking administration which is used English and expected they will adapt to work in bank.

In relation to the statement above, this subject is expected to be regular subject and not as an optional for students. It meant, is necessary to do research related to the role of this subject for development of Language and English literature study program to produce alumnus which is able to fulfill the demand of banking field work.

Based on limitation and identification of the problem that have determined by researcher, the questions of this research as follows:

1. Does English for Banking subject have a positive role toward students' readiness of Language and English Literature Universitas Negeri Manado to enter field of work?

2. Does English for Banking subject have a negative role toward students' readiness of Language and English Literature Universitas Negeri Manado to enter field of work?

\section{Purpose of the Research}

The aim of this research as follows:

1. To identify the role of English for Banking subject toward students' readiness of Language and English Literature Universitas Negeri Manado to enter field of work.

\section{Methods}

This research is the kind of causal research where the researcher will investigate the influence of English for Banking toward students' readiness in Language and English Literature Universitas Negeri Manado to enter field of work. Casual research is used to assess the relation cause and effect between variable. This research used qualitative method and linear regression analysis. Qualitative method was helpful for complex problem (Anderson et.al. 2008: 6).

\section{Population and Sample}

The population of this research is the student of Language and English Literature study Program, Faculty of Language and Art Universitas Negeri Manado. The sample of this research is the student of IV semester of Language and English Literature study program, Faculty of Language and Art Universitas Negeri Manado (UNIMA).

\section{Data Collection method}

Data collection is the various way to collect the data itself, assembling, taking, or embracing data research. Questionnaire is one of the ways collecting the data. The questionnaire used was the the closed questionnaire. This kind of questionnaire consists of various items ( statement or question within the certain options. (Bungin, 133). Respondents had been asked to sign the option that relate to him/her. Questionnaire would be distributed for the students and lecturers who were involved in the teaching- learning process of the subject 'English for Banking'. 
The scale used on this research is called Likert scale. According to Suwartono, Likert scale is used to measure attitude, opinion, and perception of someone or group of people about the social phenomenon. By the Likert scale, the variable that would be measured has to be explained to become variable indicator. Afterwards, the indicator is made as a standard to arrange the instrumental items that can be appeared as question or statement. The answer of each instrumental item that using Likert scale has a gradation from very positive to very negative and it can be formed as words.

Table 1. Likert scale

\begin{tabular}{|c|c|}
\hline Statement & Point \\
\hline Very agree & 5 \\
\hline agree & 4 \\
\hline Hesitant/Neutral & 3 \\
\hline Disagree & 2 \\
\hline Very disagree & 1 \\
\hline
\end{tabular}

\section{Research Prochedure}

This research was made in four months started by the preparation until arranging the report by the schedule as follows:

Table 2. Research Prochedure

\begin{tabular}{|l|l|l|l|l|l|}
\hline No & Research Activity & \multicolumn{3}{|l|}{ Research periode } \\
\cline { 4 - 6 } & & Feb & Mar & April & Mei \\
\hline & $\begin{array}{l}\text { Proposal arranging and } \\
\text { bibliography }\end{array}$ & X & & & \\
\hline 2. & Data Collecting & & X & & \\
\hline 3. & Data Analysis & & & X & \\
\hline 4. & Seminar result & & & X & \\
\hline 5. & Report arrangement & & & & X \\
\hline
\end{tabular}

\section{Hipothesis Test}

To be able to test the hopothesis, statistical analysis like $\mathrm{T}_{\text {test }}$ needs to be calculated. $T_{\text {test }}$ will be useful in the situation where the researcher needs to know the relation between dependent variable and Independent one. When $\mathrm{T}_{\text {test }}$ is given and being compared with $\mathrm{T}_{\text {table, hypothesis }}$ can be examined.

\section{Research Setting}

The research had been done at Language and English literature study program, Manado state university, with sixteen respondents. 
Journal of Educational Method and Technology Vol. 1 No. 2, September 2018

P-ISSN 2622-8459 E-ISSN 2622-8467

http://ejournal.unima.ac.id/index.php/jemtec

\section{Results and Discussion}

Language and English literature study program, faculty of language and arts Manado State University

- Vision

To become the superior study program in terms of producing human resource who can participate in academy and to be able to compete in region, national, and international.

\section{- Mission}

1) To produce the academician degree holder who has the language and literature background that can fulfil the requisite of the work place.

2) Implementing the research activity to improve the knowledge in language and literature fields.

3) Implementing the dedication to the society in language and literature fields.

4) Developing and increasing the cooperation with another person/group as the user continuously.

Therefore, all the activities in English and literature study program is refered to the vision and mission above also interms of including the subject " English for Banking ' in the curriculum started as an objective subject. This matter is specifically to bring the first mission which is to fulfil the requisite of the work place.

\section{Description of the subject 'English for Banking'}

'English for Banking' subject is the brand new subject that was given firstly for the fourth semester student of English and literature study program, Faculty of language and arts, Manado State University in the 2016/2017 academic year which has never been given ever since this study program had started. This subject, which its status is still the objective subject or optional is arranged by various main topics that needs to be learned in relation with banking field such as : The Understanding of Banking, The Business of Providing Financial Services to Consumers and Business, Checking Accounts, Savings Accounts and Time Deposits, Loans, and Basic Cash Management Services such as Check Cashing and Foreign Currency Exchanges, Types of Banks Specializing in Offering Basic Banking Services, Commercial Banks, Savings and Loan Associations, Saving Banks, and Credit Unions (Banking Institutions), Banking Services, Banking Regulation, Central Banking, dan International Banking.

This is quoted from the catalogue book of English Education Department as a standard of structure curriculum implemented in 2002, in English for Business study program (Senduk 42). This subject was given for sixteen meeting with two 
Journal of Educational Method and Technology Vol. 1 No. 2, September 2018

P-ISSN 2622-8459 E-ISSN 2622-8467

http://ejournal.unima.ac.id/index.php/jemtec

credits. Every meeting has different style of learning process include lecturing and discussion.

\section{Hypothesis}

This research aimed to find out the implementation result of "English for Banking Subject" toward students' readiness in field of work as dependent variable.

\section{Ttest}

$\mathrm{T}$ test used to the impact of independent variable toward dependent variable. This hypothesis implemented by comparing $\mathrm{T}_{\text {count }}$ with $\mathrm{T}_{\text {table }}$ with significant level $45 \%(\alpha=0,05)$. If $\mathrm{t}$ count $>\mathrm{t}$ table means $\mathrm{H} 2$ rejected and $\mathrm{H} 1$ received and if $\mathrm{t}$ count $<\mathrm{t}$ table so $\mathrm{H} 2$ received and $\mathrm{H} 1$ rejected.

Table 3. Regression Linier Result Coefficients ${ }^{\mathrm{a}}$

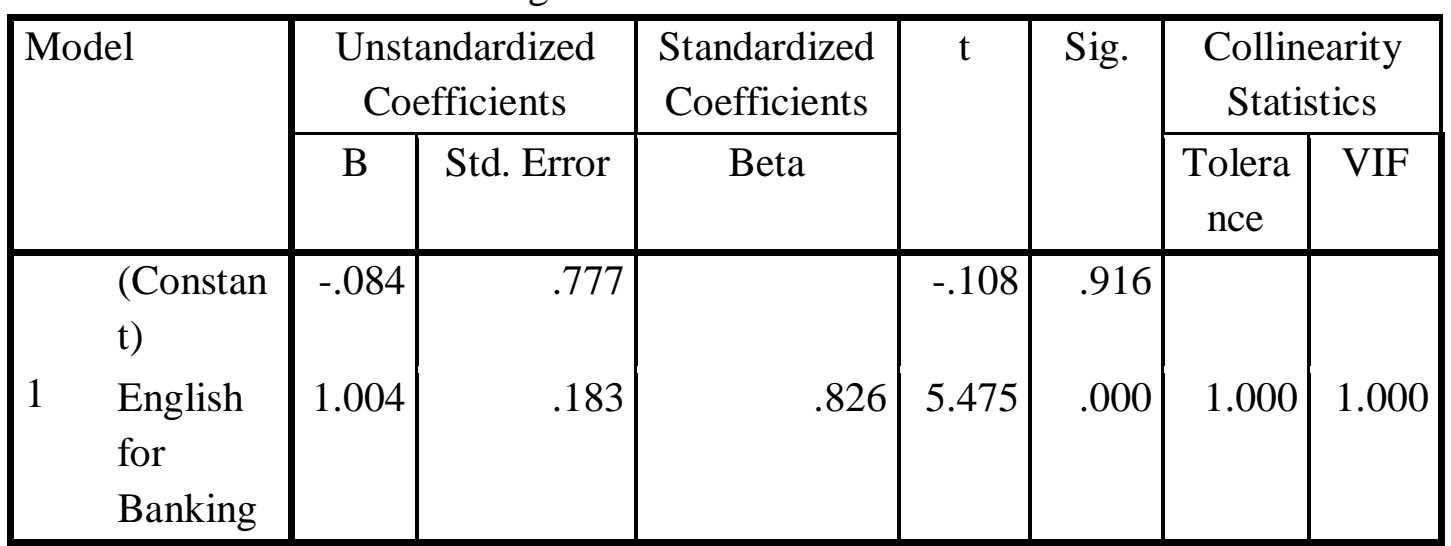

a. Dependent Variable: Students' readiness to join field of work

source: SPSS ver.22 (2017)

This is T table, calculation as follows:

TINV $=0.05, \mathrm{n}-\mathrm{k}$

TINV $=0.05,16-1$

$\mathrm{TINV}=2.131$

1. English for Banking toward students' readiness to facing field of work.

$\mathrm{H} 1$ received if $\mathrm{T}_{\text {count }}>\mathrm{T}_{\text {table }}$, English for Banking has positive impact toward students' readiness of language and literature study program Universitas Negeri Manado (UNIMA) to facing field of work. Table 4.1 showed $\mathrm{T}_{\text {count }}$ is $5.475>$ $\mathrm{T}_{\text {table }}$ because of $\mathrm{T}_{\text {count }}$ bigger than $\mathrm{T}_{\text {table }}, \mathrm{H} 1$ received and $\mathrm{H} 2$ rejected. It meant subject English for Banking had positive impact toward students' readiness of Language and literature study program in field of work. 
Journal of Educational Method and Technology Vol. 1 No. 2, September 2018

P-ISSN 2622-8459 E-ISSN 2622-8467

http://ejournal.unima.ac.id/index.php/jemtec

\section{Discussion}

According to hypothesis result above, it meant subject "English for Banking" had positive impact for students' readiness of Language and literature study program in field of work. After data analysis by questionnaire to the students can be concluded subject of "English for Banking" was given of English for banking vocabularies. It meant this subject was given to the students to provide them to have a chance to work bank.

After conducting this research, it can be concluded that subject "English for Banking" has positive impact toward students' readiness to work in bank. This subject is eligible to be applied in language and literature study program to adapt and work in bank.

\section{Conclusion}

According to this research it can be concluded that subject "English for Banking" has positive impact toward students' readiness to work in bank. Secondly, subject of "English for Banking" is eligible to be provided in language and literature study program.

Because of subject "English for Banking" had positive impact to language and literature study program FBS UNIMA. It is suggested this subject should become obligatory subject not as an optional subject.

\section{References}

Bungin, Burhan., Metodologi Penelitian Kuantitatif: Komunikasi, Ekonomi, dan Kebijakan publik serta Ilmu-ilmu Sosial Lainnya. Kencana Prenada Media Group. Surabaya: 2004.

Narwoko, J Dwi. dan Bagong Suyanto. Sosiologi Teks Pengantar dan Terapan. Jakarta: Kencana Predana Media Group, 2006.

Senduk, A. G., Katalog Jurusan Pendidikan Bahasa Inggris, FBS UNIMA, Tondano, 2002.

Suwartono, Dasar-Dasar Metodologi Penelitian, Andi: Yogyakarta. 2014.

...http://resourcecentre.foodrisc.org/mixed-methods-

research $185 . h$ tml

..http://www.landasanteori.com/2015/10/pengertian-peranan-definisi

menurut.html.

http://www.materibelajar.id/2016/01/definisi-peran-dan-

pengelompokan-peran.html 